Military Technical College

Kobry El-Kobbah,

Cairo, Egypt

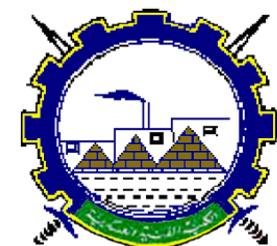

I.C.E.E.2016 $8^{\text {th }}$ International Conference

on

Chemical \& Environmental

Engineering

$19-21$ April 2016

\title{
EM-4
}

\section{Spectrally Adapted Red Flares with Enhanced Color Quality and Luminous Intensity}

\author{
Ramy Sadek, Mohamed Kassem, Mohamed Abdo, Sherif Elbasuney*
}

\begin{abstract}
The production of bright light, with vivid color, is the primary purpose of signaling, tracing, illuminating devices, highway distress flares, and aerial fireworks. This study, reports on the development of red flame compositions with enhanced performance in terms of luminous intensity, color quality, and action time to standard red flare R-284 NATO. A systematic study was conducted in an attempt to optimize different factors that could affect the red flare performance. The explored parameters are the binder type and fuel, as well as the proper assortment between fuel/oxidizer and color emitter/color intensifier. The light intensity as well as the imprint spectra of developed red flares to reference (R-284 NATO) was measured using digital luxmeter DL 1076 by Miltronics and UV-Vis. spectrometer USB 4000 by Ocean optics. The main giving of this study is that the light intensity of R-284 NATO was increased by $72 \%$, the color quality was also improved by $60 \%$ by means of optimizing the ratio of color intensifier poly vinyl chloride (PVC) to color source $\mathrm{Sr}\left(\mathrm{NO}_{3}\right)_{2}$ using novel metal fuel (Al). This is the first time ever; aluminum fuel has been employed in red flare formulations. Aluminum-based formulations were found to maximize the formation of red color reactive emitting species $(\mathrm{SrCl})$, and to minimize the interfering incandescent emission resulted from $\mathrm{MgO}$ and SrO. The combustion gaseous products particularly the Wt.\% of active red color emitting species was evaluated using chemical equilibrium thermodynamic code named ICT (Institute of Chemical Technology in Germany, Virgin 2008) to judge the quality of the developed red light. The improvement in red flare performance was achieved by implementing the general rule that the color intensifier should be in the range from 10-15 Wt.\% of the total composition. Applied loading pressure (for sample preparation) higher than 50 bars was found to decrease the light intensity. This study might open the route for the development of tailored and effective colored flame compositions as well as infra-red flares.
\end{abstract}

Keywords: Pyrotechnics, Red Flare, Luminous intensity, Color quality, Spectrum.

\footnotetext{
* Egyption Armed Forces
} 
Military Technical College

Kobry El-Kobbah,

Cairo, Egypt

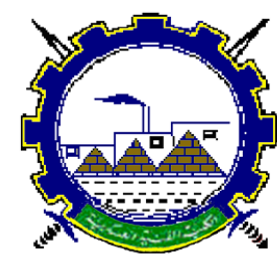

I.C.E.E.2016 $8^{\text {th }}$ International Conference

on

Chemical \& Environmental

Engineering

$19-21$ April 2016

\section{Introduction}

Pyrotechnic, the art of making fire, was known for many years [1, 2]. Almost all pyrotechnic compositions should contain an oxidizer, fuel, and binder [3-5]. Pyrotechnic compositions have wide range of applications including heat compositions, gas generator, smoke, noise, delays, and colored flame compositions [6-10]. The production of bright light, with vivid color, is the primary purpose for many pyrotechnic compositions [11-13]. Certain elements and compounds when heated to high temperature have the unique property of emitting lines or narrow bands of light in the visible region (380 to 780 nanometers) [14-16]. Such emitting species is targeted to be effectively produced during pyrotechnic combustion for colored flame production [17, 18]. Nothing in pyrotechnics is as difficult as the creation of reproducible visual effects $[19,20]$. The visible colors can be classified to main characteristic frequency ranges as represented in table 1.

Table 1: Wavelength ranges of spectral colors

\begin{tabular}{cc}
\hline Color & Wavelength, nm \\
\hline Violet & $380-435$ \\
Blue & $435-480$ \\
Green & $500-560$ \\
Yellow & $580-595$ \\
Red & $650-780$ \\
Infrared & $>780$ \\
\hline
\end{tabular}

Only a few elements can be used to impart a color to a pyrotechnic flame. Such elements are called the color source, for instance strontium (red), barium (green), copper (green or blue), and sodium (yellow) [21-23]. These elements have certain properties and characteristics in common which contribute to colored light emission [24].

Strontium, barium, copper emits color by forming their halides; this type of emission is known as molecular emission [25]. A yellow flame color is easily achieved by atomic emission from sodium. Sodium emits color by itself as an atom in the vapor state [21]. Atomic emission is characterized by sharp discrete wave length, while molecular emission is characterized by broad band emission [26, 27]. 
Military Technical College

Kobry El-Kobbah,

Cairo, Egypt

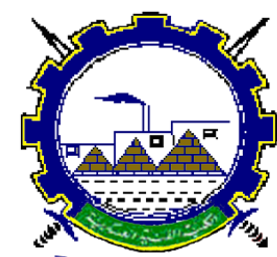

I.C.E.E.2016 $8^{\text {th }}$ International Conference

on

Chemical \& Environmental

Engineering

$19-21$ April 2016

Light emission has a variety of applications, ranging from military signals, tracking, illuminating devices, highway distress flares, and spectacular aerial fireworks [28]. Fluorine and Chlorine are the most reactive halogens used in pyrotechnic mixtures. Fluorine is widely used in IR thermal decoy flares, while chlorine is used for illuminators and color flares. Chlorine was found to be an essential element to create different molecular emitting species, it serves two important functions in a pyrotechnic flame:

1- It forms volatile chlorine-containing molecular species with the color producing metals, ensuring a sufficient concentration of emitters in the vapor phase.

2- These chlorine-containing species are good emitters of narrow bands of visible light, producing the observed flame color.

Without both of these properties, volatility and light emission with good colors would be difficult to achieve [21]. Therefore, chlorine is used as color intensifier to enhance the production of colored flames in the visible band, and to achieve a good output. Without Chlorine good colors would be difficult to be achieved [29].

Magnesium was used in pyrotechnic fields since 1865, and developed for various radiation effects such as white and colored, visible, ultraviolet, and infrared compositions. In an oxidizing flame, the magnesium is converted to magnesium oxide $(\mathrm{MgO})$. Magnesium oxide, with high-melting point, is an excellent white light emitter by incandescence. Also, the high heat output of magnesium-containing compositions aids in achieving high flame temperatures but this may affect the color quality [30].

Aluminum was used pyrochemically since 1895, and was particularly used in thermite compositions as a heat source but also it had been developed as a part of light production.

The production of a vividly colored flame is a challenging problem than creating white light. To obtain high quality colored flame, a delicate balance between different factors is required; these factors including:

* An atomic or molecular species that will emit the desired wavelength.

* The emitting species must be sufficiently volatile to exist in the vapor state.

* Sufficient heat should be generated to produce the excited emitter.

* Heat is necessary to volatilize and excite the emitter, but must not exceed the dissociation temperature of the emitting molecular species.

* The presence of incandescent solid or liquid particles in the flame can adversely affect color quality by the emission of electromagnetic radiation (including visible light) from a hot body as a result of its temperature.

Magnesium or aluminum metal fuel can yield high flame temperatures and high overall intensity, but broad emission from incandescent metal-oxide products may lower color purity [31-33].

The usage of these fuel metals in pyrotechnics: 
Military Technical College

Kobry El-Kobbah,

Cairo, Egypt

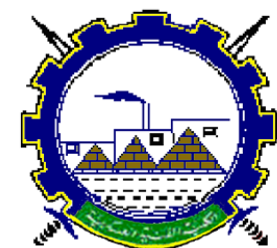

I.C.E.E.2016 $8^{\text {th }}$ International Conference

on

Chemical \& Environmental

Engineering

$19-21$ April 2016

Magnesium is the main fuel of high intensity military flares and not preferred in colored lights.

Aluminum is the preferred fuel used in flash compositions and in thermite and thermate.

The alloys find limited use in some flash mixtures and those with low aluminum content as bodies of fire-bombs [34]. Table 2 [31, 35] mentioned the main difference between magnesium and aluminum and their use in different pyrotechnic mixtures.

Table 2: Properties and usage of magnesium and aluminum as fuels in pyrotechnic mixtures

\begin{tabular}{|c|c|c|}
\hline & Magnesium & Aluminum \\
\hline Appearance & Shiny grey solid & Silvery gray metallic \\
\hline Atomic number & 12 & 13 \\
\hline$M_{w t}$ & 24 & 27 \\
\hline Element category & Alkaline earth metal & Post transition metal \\
\hline Electronegativity & 1.31 & 1.61 \\
\hline Density & $1.738 \mathrm{~g} / \mathrm{cm}^{3}$ & $2.7 \mathrm{~g} / \mathrm{cm}^{3}$ \\
\hline Discovery year & 1755 & 1825 \\
\hline Properties & $\begin{array}{ll}\text { - } & \text { very reactive metal } \\
\text { - } & \text { oxidized by moist air } \\
\text { - } & \text { readily reacts with all } \\
\text { acids even the weak } \\
\text { species } \\
\text { - } \\
\text { - } \\
\text { highly flammable metal } \\
\text { light that includes strong } \\
\text { ultraviolet }\end{array}$ & $\begin{array}{ll}\text { - } & \text { reasonable in cost } \\
\text { - } & \text { lightweight } \\
\text { - } & \text { stable in storage } \\
\text { - } & \text { available in a variety of } \\
\text { particle shapes and sizes } \\
\text { - used to achieve a variety } \\
\text { of effects }\end{array}$ \\
\hline Melting point & $649^{\circ} \mathrm{C}$ & $660^{\circ} \mathrm{C}$ \\
\hline Boiling point & $1,107^{\circ} \mathrm{C}$ & $2,500^{\circ} \mathrm{C}$ \\
\hline Heat of combustion & $5.9 \mathrm{kcal} / \mathrm{gram}$ & $7.4 \mathrm{kcal} / \mathrm{gram}$ \\
\hline Heat of vaporization & $128 \mathrm{~kJ} / \mathrm{mol}$ & $284 \mathrm{~kJ} / \mathrm{mol}$ \\
\hline Crystal structure & Hexagonal close packed & Face centered cubic \\
\hline Forms & $\begin{array}{l}\text { Bars, rods, ribbon, granular } \\
\text { or fine flake }\end{array}$ & $\begin{array}{l}\text { Granular, Fine flakes, large } \\
\text { flakes, acicular or atomized }\end{array}$ \\
\hline
\end{tabular}


Military Technical College

Kobry El-Kobbah,

Cairo, Egypt

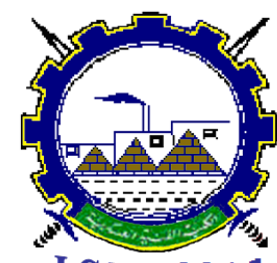

I.C.E.E.2016 $8^{\text {th }}$ International Conference

on

Chemical \& Environmental

Engineering

$19-21$ April 2016

Nowadays, the aluminum is the preferred metallic fuel for different pyrotechnic compositions, while the magnesium runs in the second place [26].

Also, any interfering atomic and molecular emitters must be avoided or at least minimized. For instance, the intense yellow-orange atomic emission from sodium $(589 \mathrm{~nm})$ will overwhelm other colors [34, 36-38].

In Red flares, the emission take place in the red region of the visible spectrum $(650-780$ $\mathrm{nm})$. The main emitting species for red color are strontium mono-chloride $(\mathrm{SrCl})$, strontium hydroxide $(\mathrm{SrOH})$, and strontium hydride $(\mathrm{SrH}) . \mathrm{SrCl}$ (the main red color emitter) is unstable at room temperature and when formed in the flame it will have enough energy to emit the required red color. This active species are formed only during combustion of red flare formulation. $\mathrm{Sr}\left(\mathrm{NO}_{3}\right)_{2}$ is a good oxidizing species; it is often used as an oxidizer and color source [39-41].

The main purpose of this study is to maximize the formation of this active species in the combustion flame, by optimization of red flare constituents. The investigated parameters included different binders, oxidizers, fuels and color intensifier to color source ratio. Red flares with enhanced performance, in terms of color quality, color intensity, and duration time, were developed. The combustion gasses and combustion temperature for different red flare formulation was evaluated using chemical equilibrium computer program named ICT Thermodynamic Code (Institute of Chemical Technology in Germany, virgin 2008). Red flare formulations were prepared and pressed in the desired dimension and their spectral performance was evaluated using ocean optics USB 4000 spectrometer and a Miltronics DL 1076 digital lux-meter. The burning process was also video recorded using Nikon coolpix L320 handy cam.

\section{Experimental work}

\subsection{Chemicals and materials}

The main constituents for red flare manufacture include: oxidizer, metal fuel, color source, binder, and color intensifier. One constituent can have a dual function; $\operatorname{Sr}\left(\mathrm{NO}_{3}\right)_{2}$ can act as a color source and oxidizer. Poly vinyl chloride (PVC) can act as a binder and as color intensifier. Sieving was carried out to achieve the proper particle size less than $150 \mu \mathrm{m}$, only the ribbon magnesium requires a crushing process before sieving. Table 3 tabulates a list of chemicals used in this study.

\subsection{Red flare formulation}

Artillery red tracer, which gives a deep red color, known as R-284 NATO was employed as a reference. The chemical composition of such tracer was $55 \% \operatorname{Sr}\left(\mathrm{NO}_{3}\right)_{2}, 28 \% \mathrm{Mg}$ and $17 \%$ PVC [42]. A systematic study to develop enhanced red flare was conducted; this study includes the following main steps: 
Military Technical College

Kobry El-Kobbah,

Cairo, Egypt

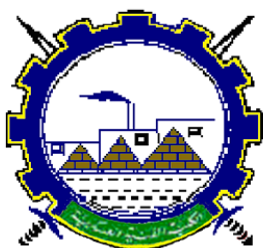

I.C.E.E.2016 $8^{\text {th }}$ International Conference

on

Chemical \& Environmental

Engineering

$19-21$ April 2016

- Fuel rich / stoichiometric formulations $\left(\mathrm{F}_{\mathrm{o}}-\mathrm{F}_{1}\right)$.

* Type of binder $\left(\mathrm{F}_{2}-\mathrm{F}_{3}\right)$.

* Type of fuel $\left(\mathrm{F}_{4}\right)$.

* Fuel to oxidizer ratio $\left(\mathrm{F}_{5}-\mathrm{F}_{8}\right)$.

* Color intensifier to color source at different fuel types $\left(\mathrm{F}_{9}-\mathrm{F}_{12}\right)$.

The average result of three test for each formulation was calculated and compared to indicate the repeatability of the preparation process and minimize the errors .Table 4 summarizes the chemical composition of different investigated formulations.

Table 3: The function and structure of different used chemicals

\begin{tabular}{|c|c|c|c|c|}
\hline Chemicals & Function & Structure & Grade & Supplier \\
\hline Strontium nitrate & $\begin{array}{c}\text { Oxidizer \& } \\
\text { color source }\end{array}$ & $\mathrm{Sr}\left(\mathrm{NO}_{3}\right)_{2}$ & $\begin{array}{c}\text { Analytical grade, } \\
\geq 98 \%\end{array}$ & $\begin{array}{c}\text { Alpha } \\
\text { chemika }\end{array}$ \\
\hline Magnesium & Fuel & $\mathrm{Mg}$ & $98 \%$,ribbon & $\begin{array}{c}\text { Alpha } \\
\text { chemika }\end{array}$ \\
\hline Aluminum & Fuel & $\mathrm{Al}$ & $99 \%$,fine powder & $\begin{array}{c}\text { Alpha } \\
\text { chemika }\end{array}$ \\
\hline Polyvinyl chloride & $\begin{array}{c}\text { Binder \& color } \\
\text { intensifier }\end{array}$ & $\left(\mathrm{C}_{2} \mathrm{H}_{3} \mathrm{Cl}\right) \mathrm{n}$ & $\begin{array}{c}\text { Analytical grade, } \\
\geq 95 \%, \text { fine } \\
\text { powder }\end{array}$ & $\begin{array}{c}\text { Alpha } \\
\text { chemika }\end{array}$ \\
\hline Arabic gum & $\begin{array}{c}\text { Binder \& color } \\
\text { intensifier }\end{array}$ & $\left(\mathrm{C}_{12} \mathrm{H}_{7} \mathrm{ClN}_{2} \mathrm{O}_{3}\right) n$ & $\begin{array}{c}\text { Analytical grade, } \\
\geq 95 \%, \text { fine } \\
\text { powder }\end{array}$ & $\begin{array}{c}\text { Alpha } \\
\text { chemika }\end{array}$ \\
\hline Shellac & Binder & $\left(\mathrm{C}_{30} \mathrm{H}_{50} \mathrm{O}_{11}\right) \mathrm{n}$ & $\begin{array}{c}\text { commercial } \\
\text { grade }\end{array}$ & $\begin{array}{c}\text { Alpha } \\
\text { chemika }\end{array}$ \\
\hline
\end{tabular}

Red flare development should emphasize mixing of different ingredients to the molecular level, good homogenization, and accepted mechanical properties [8]. In this study, the red flares manufacture included eight main steps as follow:

1. Sieving of solid particles to fine powder less than $100 \mu \mathrm{m}$.

2. Intimate mixing of oxidizer, fuel and binder.

3. Granulation to retain the homogeneity of the composition otherwise light and dense materials might segregate during transportation, processing, and storage.

4. Filling, by Loading $25 \mathrm{gm}$ of the composition into metal cylinder of $2.5 \mathrm{~cm}$ diameter.

5. The final product was achieved by applying a pressure of 100 bars.

All investigated formulations were prepared with the same methodology, to avoid any variability which would affect the performance. Figure 1 shows the main steps for manufacture of red flares.

The used equipment in red flare preparation and spectral testing are scheduled in table 5. 
Military Technical College

Kobry El-Kobbah,

Cairo, Egypt

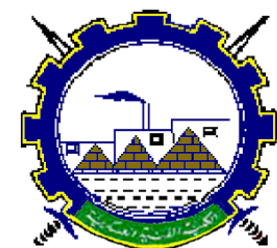

I.C.E.E.2016 $8^{\text {th }}$ International Conference

on

Chemical \& Environmental

Engineering

$19-21$ April 2016

Table 4: Chemical composition of developed red flares

\begin{tabular}{|c|c|c|c|c|c|c|c|}
\hline Formulation & $\begin{array}{c}\mathrm{Sr}\left(\mathrm{NO}_{3}\right)_{2} \\
\text { Wt. } \%\end{array}$ & $\begin{array}{c}\text { Mg } \\
\text { Wt.\% }\end{array}$ & $\begin{array}{c}\text { Al } \\
\text { Wt.\% }\end{array}$ & $\begin{array}{c}\text { PVC } \\
\text { Wt.\% }\end{array}$ & $\begin{array}{c}\text { Arabic } \\
\text { Gum } \\
\text { Wt. } \%\end{array}$ & $\begin{array}{c}\text { Shellac } \\
\text { Wt.\% }\end{array}$ & Comment \\
\hline $\mathbf{F}_{\mathbf{0}}$ & 55 & 28 & - & 17 & - & - & Reference \\
\hline $\mathbf{F}_{1}$ & 73.8 & 9.2 & 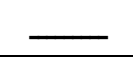 & 17 & - & 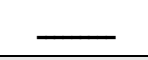 & Stoichometric \\
\hline $\mathbf{F}_{2}$ & 55 & 28 & - & - & 17 & $\bar{z}$ & \\
\hline $\mathbf{F}_{3}$ & 55 & 28 & 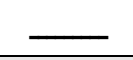 & - & 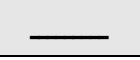 & 17 & Binder type \\
\hline $\mathbf{F}_{4}$ & 55 & - & 28 & 17 & - & - & Fuel type \\
\hline $\mathbf{F}_{5}$ & 61 & 22 & - & 17 & - & - & \\
\hline $\mathbf{F}_{6}$ & 58 & 25 & 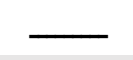 & 17 & 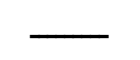 & 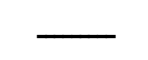 & Fuel to \\
\hline $\mathbf{F}_{7}$ & 61 & - & 22 & 17 & 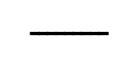 & $\overline{\mathrm{C}} \mathrm{x} \cdot \mathrm{x}$ & oxidizer ratio \\
\hline$F_{8}$ & 58 & 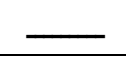 & 25 & 17 & - & - & \\
\hline $\mathbf{F}_{9}$ & 65 & 28 & 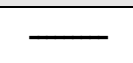 & 7 & 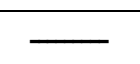 & 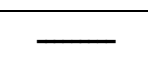 & Color source \\
\hline $\mathbf{F}_{10}$ & 60 & 28 & & 12 & - & 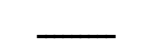 & to color \\
\hline $\mathbf{F}_{11}$ & 65 & & 28 & 7 & & & intensifier at \\
\hline $\mathbf{F}_{12}$ & 60 & 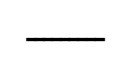 & 28 & 12 & 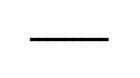 & 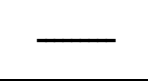 & $\begin{array}{l}\text { different fuel } \\
\text { types }\end{array}$ \\
\hline
\end{tabular}

Table 5: Equipment used in red flare preparation and spectral measurements

\section{Equipment}

\section{Function}

Cizeta 20 ton electronic $\bullet$ Pressing the mixture forming a coherent homogenized final press product for transportation, handling, and testing.

Die

- A steal body with the required dimensions for flare pressing.

Digital light meter

DL 1076 digital luxmeter, Miltronics, (Country)

UV-Vis. Spectrometer USB 4000 spectrometer, ocean optics, USA
- For luminous flux density measurements.

- The unit of measurement is the Lux. (also known as luxmeter).

- By unit conversion we get the light intensity in candlepower.

- For wavelength and intensity measurements.

- For wavelength and intensity measurements.

- It is responsive from 200-1100 nm (UV-Visible - NIR).

- Maximum intensity is 65000 counts.

- Gives the output spectrum of the sample.

- Detector response for a selective wavelength band.

Edmund industrial optics • To avoid spectrometer saturation with high intensity light. with lens holder 
Military Technical College

Kobry El-Kobbah,

Cairo, Egypt

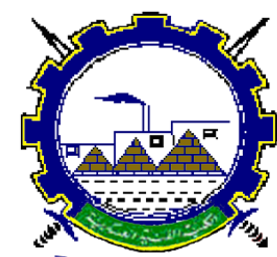

I.C.E.E.2016 $8^{\text {th }}$ International Conference

on

Chemical \& Environmental

Engineering

$19-21$ April 2016

\subsection{Spectral measurements of red flares}

Photometric tunnels are widely used to measure the imprint spectra of different pyrotechnic devices including: flares, signal, tracer, etc. The employed tunnel dimensions were $8 \mathrm{~m}$ (L) $\mathrm{X}$ $2 \mathrm{~m}(\mathrm{H}) \times 0.5 \mathrm{~m}(\mathrm{~W})$. The distance between the specimen holder and the spectrometer photodetector and luxmeter was $7 \mathrm{~m}$. A schematic of the employed photometric dark tunnel is represented in Figure 2.

The Miltronics DL 1076 digital luxmeter measured the illuminance (E) in lux (lx). The illuminace (E) was converted into luminous intensity (I) in candela (cd) by knowing the distance between the light source and the detector (d).

Equation 1 demonstrate the relation between illuminace and luminous intensity [43]:

$$
I_{(c d)}=E_{(l x)} \times\left(d_{(m)}\right)^{2}
$$

The luminous intensity (I) in candela (cd) was calculated each second during the action time of the tested composition. The average luminous intensity per time $(\mathrm{cd} / \mathrm{s})$ was calculated by measuring the summation of the area under the curve of the total luminous intensity (I) in candela (cd) divided by the burning time. The main drawback of such measurement is that it cannot provide information about color quality.

In order to judge the color quality, ocean optics USB 4000 spectrometer with Spectra Suite software was employed. This software provides the ability to measure spectra over a selective wavelength band. In this study, the detector was adapted for the measurement of the red band from $650-780 \mathrm{~nm}$ [21]. Spectral measurement was conducted, every 30 seconds, during the tested flare combustion.

After acquiring the data in an excel file, the integration of the area under the curve was conducted and divided by the burning time to retrieve the average luminous intensity $(\mathrm{cd} / \mathrm{s})$ and spectrometer response (counts/s) over the red band $(650-780 \mathrm{~nm})$ for the developed flares to reference flare [42].

\section{Results and discussion}

\subsection{Effect of binder type}

The type of binder could have a significant impact on red flare performance. The binder itself can act as color intensifier (as a source of chlorine). Shellac and Arabic gum didn't improve the light intensity to standard red flare as demonstrated in Figure 3.

Arabic gum and shellac were not effective color intensifier due to the lack of chlorine of such binders. These two binders were not supporting the formation of $\mathrm{SrCl}$ which is the main red color emitter. This assumption was confirmed through thermochemical calculations using ICT code. Table 6 shows the impact of binder type on the formation of reactive emitting species. 
Military Technical College

Kobry El-Kobbah,

Cairo, Egypt

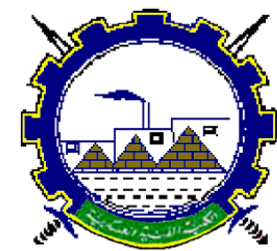

I.C.E.E.2016 $8^{\text {th }}$ International Conference

on

Chemical \& Environmental

Engineering

$19-21$ April 2016

Table 6: thermochemical reaction products for different types of binder

\begin{tabular}{cccc}
\hline & Temperature (K) & $\mathbf{S r C l}_{(\mathbf{g})} \mathbf{W t} \%$ & $\mathbf{S r O H}_{(\mathbf{g})} \mathbf{W t} . \%$ \\
\hline $\mathbf{F}_{\mathbf{0}}$ & 2916.9 & 5.431 & 2.012 \\
$\mathbf{F}_{\mathbf{2}}$ & 2995.7 & 0 & 2.559 \\
$\mathbf{F}_{\mathbf{3}}$ & 2734.7 & 0 & 1.469 \\
\hline
\end{tabular}

Table 5 confirmed that PVC is the binder of choice for red flares, as it has an effective role in supporting the formation of red color emitting species mainly $\mathrm{SrCl}$, and $\mathrm{SrOH}$. Figure 4 shows the impact of binder type on red flare imprint spectra and emission correlations to certain excited species [39].

Intense red color was achieved using PVC as a binder; PVC, with its high chlorine content, can have dual functions as a binder and color intensifier (source of chlorine) [21].

\subsection{Effect of fuel type}

$\mathrm{Mg}$ is the most commonly used fuel in pyrotechnics particularly colored flame compositions [5]. However the formation of $\mathrm{MgO}$ as black body emitter can broaden the generated spectra, and negatively impact the color quality [39]. This is why, the metal fuel of reference red flare $(\mathrm{Mg})$ was replaced by $\mathrm{Al}$ in an attempt to improve the color quality [34]. The employed binder was PVC which was found to be effective binder and color intensifier.

The average luminous intensity $(\mathrm{cd} / \mathrm{s})$ and spectrometer response (counts/s) over the red band $(650-780 \mathrm{~nm})$ of the developed flare were measured for reference flare [42]. Table 7 reports the impact of fuel type on the main spectral data.

Table 7: Impact of fuel type on red flare spectral parameters

\begin{tabular}{c|ccc}
\hline Formulation & $\begin{array}{c}\text { Average Luminous } \\
\text { intensity per time (cd/s) }\end{array}$ & $\begin{array}{c}\text { Detector response (counts/s) } \\
\mathbf{( 6 5 0}-\mathbf{7 8 0} \mathbf{~ n m )}\end{array}$ & $\begin{array}{c}\text { Burning time } \\
\mathbf{( s )}\end{array}$ \\
\hline $\mathbf{F}_{\mathbf{0}}$ & 2787.81 & 6974.56 & 25.5 \\
$\mathbf{F}_{\mathbf{4}}$ & 2718.71 & 6378.54 & 28 \\
\hline
\end{tabular}

Table 6 demonstrated that; changing fuel from $\mathrm{Mg}$ to $\mathrm{Al}$ did not improve the red flare performance. Even though Al did not improve the light intensity; the main red color emitting species $(\mathrm{SrCl})$ was increased by $58 \%$ and the incandescent emissions from $\mathrm{MgO}$ and $\mathrm{SrO}$ were no longer present in the reaction products (Table 8). 
Military Technical College

Kobry El-Kobbah,

Cairo, Egypt

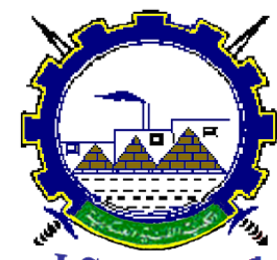

I.C.E.E.2016 $8^{\text {th }}$ International Conference

on

Chemical \& Environmental

Engineering

$19-21$ April 2016

Table 8: Thermochemical reaction products for different types of fuels

\begin{tabular}{|c|c|c|c|c|c|c|}
\hline Formulation & $\begin{array}{c}\text { Temperature } \\
\text { (K) }\end{array}$ & $\begin{array}{l}\mathrm{SrCl}_{(\mathrm{g})} \\
\text { Wt.\% }\end{array}$ & $\begin{array}{c}\text { SrOH }_{(g)} \\
\text { Wt. \% }\end{array}$ & $\begin{array}{l}\text { MgO (s) }_{\text {Wt. } \%} \\
\text { Wt. }\end{array}$ & $\begin{array}{l}\mathrm{SrO}_{(\mathrm{s})} \\
\text { Wt.\% }\end{array}$ & $\begin{array}{c}\mathrm{Al}_{2} \mathbf{O}_{3}(\mathrm{l}) \\
\text { Wt.\% }\end{array}$ \\
\hline $\mathbf{F}_{\mathbf{0}}$ & 2916.9 & 5.431 & 2.012 & 29.607 & 5.976 & 0 \\
\hline $\mathbf{F}_{4}$ & 2512.2 & 8.572 & 0.006 & 0 & 0 & 34.54 \\
\hline
\end{tabular}

$\mathrm{MgO}$ and $\mathrm{SrO}$ emits incandescent emission which increases the light intensity but could deteriorate the color quality [44]. Thus Al fuel could be the fuel of choice in red flare formulations with high color quality. Even though, the average luminous intensity per time $(\mathrm{cd} / \mathrm{s})$ and detector response (counts/s) of $\mathrm{F}_{4}$ is less than $\mathrm{F}_{0} . \mathrm{F}_{4}$ exhibited an imprint spectrum with sharp intense peaks corresponds to $\mathrm{SrCl}$ as indicated by green circle (Figure 5).

The imprint spectrum of $\mathrm{F}_{4}$ shows the formation of intense sharp peaks at 625.41 and 637.15 $\mathrm{nm}$ which are characteristic peaks of $\mathrm{SrCl}$ [39]. This finding confirms the results obtained in Table 7; that aluminum fuel could have a positive impact on color quality.

\subsection{Optimization of fuel to oxidizer ratio}

Red flare formulations based on different fuel to oxidizer ratios were developed. The investigated fuel lading levels were 22, 25 and $28 \mathrm{Wt}$.\% for both fuel types (Mg and $\mathrm{Al}$ ) with $\mathrm{PVC}$ as a binder and color intensifier. $\mathrm{F}_{6}$ with $25 \mathrm{Wt} \% \mathrm{Mg}$ fuel exhibited the highest luminous intensity. Figure 6 demonstrates the impact of fuel type/content on luminous intensity.

Even though, formulations based on $\mathrm{Mg}$ exhibited higher luminous intensity $(\mathrm{cd} / \mathrm{s})$ compared with formulations based on $\mathrm{Al}$; both fuel types exhibited controversy behavior. The increase of $\mathrm{Al}$ as a fuel causes an increase in luminous intensity, whereas $\mathrm{Mg}$ content higher than 25 Wt.\% started to decrease the luminous intensity. This effect could be ascribed to the variation of emitting species Wt.\% as well as incandescent black body emission. Table 9 tabulated the decomposition products of investigated formulations.

$\mathrm{F}_{7}$ demonstrated the highest formation of $\mathrm{SrCl}$ (the main red color emitter). The increase in $\mathrm{SrCl}$ formation was found to be $112 \%$ compared with $\mathrm{F}_{6}$. Even though $\mathrm{F}_{6}$ exhibited the highest average luminous intensity $(\mathrm{cd} / \mathrm{s})$; this could be ascribed to black emission which could be detrimental to color quality. Thus $\mathrm{F}_{7}$ could be the formulation of choice when color quality is one of the main aims. The imprint spectra of $F_{6}$, and $F_{7}$ to reference red flare are demonstrated in Figure 7. 
Military Technical College

Kobry El-Kobbah,

Cairo, Egypt

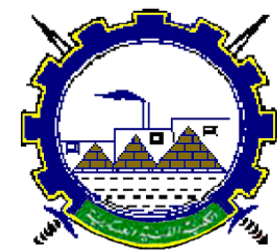

I.C.E.E.2016 $8^{\text {th }}$ International Conference

on

Chemical \& Environmental

Engineering

$19-21$ April 2016

Table 9: Decomposition products for different fuel type/ content to oxidizer

\begin{tabular}{|c|ccccccc}
\hline Formulations & $\begin{array}{c}\text { Temperature } \\
\text { (K) }\end{array}$ & $\begin{array}{c}\text { SrCl(g) } \\
\text { Wt.\% }\end{array}$ & $\begin{array}{c}\text { SrOH(g) } \\
\text { Wt.\% }\end{array}$ & $\begin{array}{c}\text { MgO (s) } \\
\text { Wt.\% }\end{array}$ & $\begin{array}{c}\text { SrO } \\
\text { (s) } \\
\text { Wt.\% }\end{array}$ & $\begin{array}{c}\text { SrO } \\
\text { (l) } \\
\text { Wt.\% }\end{array}$ & $\begin{array}{c}\mathbf{A l}_{\mathbf{2}} \mathbf{O}_{3} \\
\text { (l) } \\
\text { Wt.\% }\end{array}$ \\
\hline $\mathbf{F}_{\mathbf{0}}$ & 2916.9 & 5.431 & 2.012 & 29.607 & 5.976 & 0 & 0 \\
$\mathbf{F}_{\mathbf{4}}$ & 2512.2 & 8.572 & 0.006 & 0 & 0 & 0 & 34.54 \\
$\mathbf{F}_{\mathbf{5}}$ & 2994.9 & 3.957 & 2.002 & 26.665 & 0 & 10.522 & 0 \\
$\mathbf{F}_{\mathbf{6}}$ & 2965.6 & 4.71 & 2.113 & 28.349 & 0 & 8.144 & 0 \\
$\mathbf{F}_{\mathbf{7}}$ & 3211.5 & 9.981 & 0.772 & 0 & 0 & 0.547 & 38.938 \\
$\mathbf{F}_{\mathbf{8}}$ & 2947.7 & 9.311 & 0.11 & 0 & 0 & 0.035 & 37.266 \\
\hline
\end{tabular}

$\mathrm{F}_{7}$ exhibited the most intense red color peaks resulting from $\mathrm{SrCl}$ emission as indicated by the green arrows. The discrete emission of $\mathrm{SrCl}$ at $625.41,637.15,661.83$ and $675.53 \mathrm{~nm}$ can secure high quality red light. This finding confirms the results obtained in Table 8 . Thus high quality light could be achieved compared with reference red flare.

\subsection{Optimization of color source to color intensifier}

PVC can act as a binder and color intensifier; the optimum ratio of color source $\operatorname{Sr}\left(\mathrm{NO}_{3}\right)_{2}$ to color intensifier (PVC) was optimized at different fuel types (Mg \& Al). The dramatic and superior change in red flare performance was achieved with PVC at $12 \mathrm{Wt}$.\% with Al fuel. Red flare $\left(\mathrm{F}_{12}\right)$ exhibited the highest average luminous intensity $(\mathrm{cd} / \mathrm{s})$ as demonstrated in Figure $8 . \mathrm{F}_{11}$ also exhibited superior performance to reference red flare.

$\mathrm{F}_{12}$ with highest average luminous intensity $(\mathrm{cd} / \mathrm{s})$, could exhibit high color quality as well due to the intense formation of $\mathrm{SrCl}$ and the elimination of any incandescent emission due to $\mathrm{MgO}$. The gaseous decomposition products were investigated using ICT code (Table 10).

Table 10: Impact of color intensifier to color source on red color emitting species

\begin{tabular}{c|cccccccc}
\hline \multirow{3}{*}{ Formulation } & $\begin{array}{c}\text { Temperature } \\
(\mathrm{K})\end{array}$ & $\begin{array}{c}\mathrm{SrCl} \\
(\mathrm{g})\end{array}$ & $\begin{array}{c}\mathrm{SrOH} \\
(\mathrm{g})\end{array}$ & $\begin{array}{c}\mathrm{MgO} \\
(\mathrm{s})\end{array}$ & $\begin{array}{c}\mathrm{MgO} \\
(\mathrm{l})\end{array}$ & $\begin{array}{c}\mathrm{SrO} \\
(\mathrm{s})\end{array}$ & $\begin{array}{c}\mathrm{SrO} \\
(\mathrm{l})\end{array}$ & $\begin{array}{c}\mathrm{Al}_{2} \mathrm{O}_{3} \\
(\mathrm{l})\end{array}$ \\
& & $\mathrm{Wt} \%$ & $\mathrm{Wt} \%$ & $\mathrm{Wt} . \%$ & $\mathrm{Wt} \%$ & $\mathrm{Wt} . \%$ & $\mathrm{Wt} . \%$ \\
\hline $\mathrm{F}_{0}$ & 2916.9 & 5.431 & 2.01 & 29.61 & 0 & 5.976 & 0 & 0 \\
$\mathrm{~F}_{4}$ & 2512.2 & 8.572 & 0.01 & 0 & 0 & 0 & 0 & 34.54 \\
$\mathrm{~F}_{9}$ & 3172 & 2.173 & 1.29 & 0 & 36.79 & 0 & 21.17 & 0 \\
$\mathrm{~F}_{10}$ & 3105 & 3.817 & 2.07 & 29.01 & 0 & 0 & 12.72 & 0 \\
$\mathrm{~F}_{11}$ & 3636.8 & 6.905 & 1.368 & 0 & 0 & 0 & 0 & 48.91 \\
$\mathrm{~F}_{12}$ & 3299.3 & 10.01 & 0.5 & 0 & 0 & 0 & 0 & 43.97 \\
\hline
\end{tabular}

$\mathrm{F}_{12}$ exhibited the highest content of red color emitting species $(\mathrm{SrCl})$ in combustion gaseous products; $\mathrm{SrCl}$ was increased by $90 \%$ compared to reference red flare. The absence of $\mathrm{MgO}$ 
Military Technical College

Kobry El-Kobbah,

Cairo, Egypt

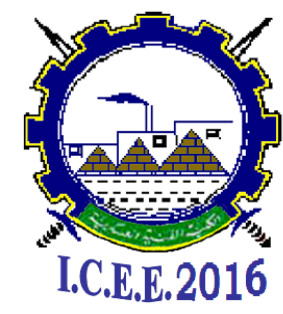

$8^{\text {th }}$ International Conference

on

Chemical \& Environmental

Engineering

$19-21$ April 2016

and $\mathrm{SrO}$ could secure high spectrum quality. $\mathrm{F}_{11}$ also showed similar behavior, the main advantages of $\mathrm{F}_{11}$ is the formation of $\mathrm{SrOH}$ which is red color emitter as well as $\mathrm{SrCl}$. Figure 9 shows the imprint spectrum of $F_{12}$ and $F_{11}$ to $F_{0}$.

The imprint spectra of $F_{11}$ and $F_{12}$ (Fig. 9) confirmed the finding that Al fuel could be the metal of choice for new red flare composition with enhanced color quality. Thanks to the optimum ratio of color source to color intensifier, which can secure high intensity. Furthermore aluminum has a high chemical stability compared with magnesium fuel. Aluminum surfaces are readily oxidized by the oxygen in the air, and a tight surface coating of aluminum oxide $\left(\mathrm{Al}_{2} \mathrm{O}_{3}\right)$ is formed that protects the inner metal from further oxidation. Hence, aluminum powder can be stored for extended periods with little loss of reactivity due to air oxidation. On the other hand, magnesium is a very reactive metal. It is oxidized by moist air to form magnesium hydroxide, $\mathrm{Mg}(\mathrm{OH})_{2}$, and it readily reacts with all acids, including weak species such as vinegar (5\% acetic acid) and boric acid. The reactions of magnesium with water and acid (HX) are demonstrated by Equations $2 \& 3$ :

Water:

$$
\begin{aligned}
& \mathrm{Mg}+2 \mathrm{H}_{2} \mathrm{O} \rightarrow \mathrm{Mg}(\mathrm{OH})_{2}+\mathrm{H}_{2} \\
& \mathrm{Mg}+2 \mathrm{HX} \rightarrow \mathrm{MgX}_{2}+\mathrm{H}_{2}\left(\mathrm{X}=\mathrm{Cl}, \mathrm{NO}_{3} \text {, etc. }\right)
\end{aligned}
$$

Acids (HX):

Consequently, red flare formulations based on aluminum can exhibit enhanced performance as well extended service life without loss of reactivity. The optimum chemical composition of red flare was found to be $60 \mathrm{Wt} . \% \mathrm{Sr}\left(\mathrm{NO}_{3}\right)_{2}$ as both oxidizer and color source, $28 \mathrm{Wt} . \% \mathrm{Al}$ as fuel, and $12 \mathrm{Wt} . \%$ PVC as binder. This composition can secure red light with high intensity and high quality. Figure 10 demonstrates digital photos of emitted red light for the developed red flare $\left(\mathrm{F}_{12}\right)$ to reference flare. It is apparently clear that higher intensity and color quality were achieved via the optimized chemical composition. For developed red flare, the color broadening by incandescent $\mathrm{MgO}$ and $\mathrm{SrO}$ incandescent black body was eliminated.

The tailored red flare $\mathrm{F}_{12}$ was developed via the optimization of the ratio between the color intensifier (PVC) to color source $\left(\mathrm{Sr}\left(\mathrm{NO}_{3}\right)_{2}\right)$ using $\mathrm{Al}$ as a fuel. This flare exhibited an increase in the luminous intensity by $72 \%$; the color quality over the red band $(650-780 \mathrm{~nm})$ was improved by $60 \%$ to the reference. Figure 11 summarized the average luminous intensity as well as the detector response over the red band for all investigated formulation. From Figure 11 it is apparently clear that $F_{11}$ and $F_{12}$ achieved enhanced spectral performance compared to reference red flare. In the meantime the action time is an essential factor to be considered. The burning time for all developed formulations as well as the $\mathrm{Wt} . \%$ of main red color emitting species, and black body emitter are demonstrated in table 11.

Table 11 demonstrated that $F_{11}$ and $F_{12}$ exhibited an increase in the main red color emitter $(\mathrm{SrCl})$ and an elimination of any incandescent emissions (black body emission) that could affect the color quality. Furthermore, $F_{12}$ exhibited burning time similar to reference formulation with deviation of $-14 \%$. 
Military Technical College

Kobry El-Kobbah,

Cairo, Egypt

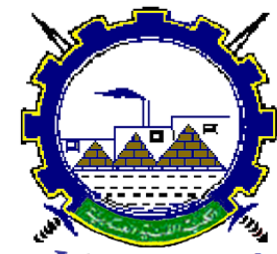

I.C.E.E.2016 $8^{\text {th }}$ International Conference

on

Chemical \& Environmental

Engineering

19 - 21 April 2016

Table 11: Results for different investigated samples

\begin{tabular}{cccccc}
\hline & \multicolumn{2}{c}{ Red color emitters } & \multicolumn{2}{c}{ Black body emitter } & \multirow{2}{*}{ Burning } \\
\cline { 2 - 5 } & $\begin{array}{c}\text { SrCl } \\
\text { Wt.\% }\end{array}$ & $\begin{array}{c}\text { SrOH } \\
\text { Wt.\% }\end{array}$ & $\begin{array}{c}\text { MgO } \\
\text { Wt.\% }\end{array}$ & $\begin{array}{c}\text { SrO } \\
\text { Wt.\% }\end{array}$ & time (s) \\
\hline $\mathbf{F}_{\mathbf{0}}$ & 5.431 & 2.012 & 29.607 & 5.976 & 25.5 \\
$\mathbf{F}_{\mathbf{1}}$ & 0.769 & 0.406 & 14.677 & 22.449 & 104 \\
$\mathbf{F}_{\mathbf{2}}$ & 0 & 2.559 & 32.833 & 20.259 & 24 \\
$\mathbf{F}_{\mathbf{3}}$ & 0 & 1.469 & 26.467 & 21.873 & 39 \\
$\mathbf{F}_{\mathbf{4}}$ & 8.572 & 0.006 & 0 & 0 & 28 \\
$\mathbf{F}_{\mathbf{5}}$ & 3.957 & 2.002 & 26.665 & 10.522 & 30 \\
$\mathbf{F}_{\mathbf{6}}$ & 4.71 & 2.113 & 28.349 & 8.144 & 26 \\
$\mathbf{F}_{\mathbf{7}}$ & 9.981 & 0.772 & 0 & 0 & 32 \\
$\mathbf{F}_{\mathbf{8}}$ & 9.311 & 0.11 & 0 & 0 & 25 \\
$\mathbf{F}_{\mathbf{9}}$ & 2.173 & 1.285 & 26.79 & 21.168 & 28 \\
$\mathbf{F}_{\mathbf{1 0}}$ & 3.817 & 2.065 & 29.012 & 0 & 28 \\
$\mathbf{F}_{\mathbf{1 1}}$ & 6.905 & 1.368 & 0 & 0 & 18 \\
$\mathbf{F}_{\mathbf{1 2}}$ & 10.01 & 0.5 & 0 & 0 & 22 \\
\hline
\end{tabular}

High loading pressure could reduce the porosity of the composition (particle-to-particle contact), and retard the passage of the hot gases down the column, so burning rate might decrease [45]. The impact of loading pressure on the burning behavior (burning rate) was evaluated for the most prominent red flare formulation $\left(F_{12}\right)$. Table 12 represents the impact of the applied loading pressure on the spectral data of the developed red flare $\left(\mathrm{F}_{12}\right)$. The increase in loading pressure could lead to an increase in the density of the composition [46]. At a certain pressing value, the composition will not react or burn, this point known also as dead-pressing, in which the material is no longer capable of being reliably initiated [47].

Table 12 Results of the applied loading pressure on the tailored red flare $\mathrm{F}_{12}$

\begin{tabular}{c|ccc}
\hline Formulations & $\begin{array}{c}\text { Average Luminous } \\
\text { intensity per time }(\mathbf{c d} / \mathbf{s})\end{array}$ & $\begin{array}{c}\text { Detector response (counts/s) } \\
\mathbf{( 6 5 0}-\mathbf{7 8 0} \mathbf{~ m m})\end{array}$ & $\begin{array}{c}\text { Burning time } \\
\mathbf{( s )}\end{array}$ \\
\hline R 25 bar & 4229.39 & 8752.11 & 23 \\
R 50 bar & 5248.6 & 10246.5 & 22 \\
R 100 bar & 3792.78 & 8641.72 & 22 \\
R 150 bar & 3687.47 & 8342.06 & 22.33 \\
\hline
\end{tabular}

The highest value for average luminous intensity $(\mathrm{cd} / \mathrm{s})$ as well as detector response (counts/s) was found to be at applied pressure of 50 bars. This can be ascribed to the fact that pressing 
Military Technical College

Kobry El-Kobbah,

Cairo, Egypt

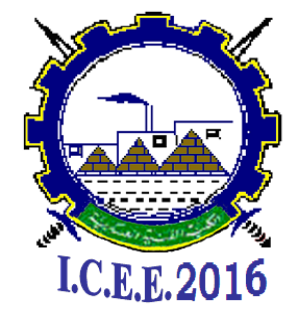

$8^{\text {th }}$ International Conference

on

Chemical \& Environmental

Engineering

$19-21$ April 2016

pressure higher than 50 bars could minimize the air voids, rendering diffusion of hot gasses into the column charge and minimize the formation of active red color emitting species. Figure 12 shows the effect of pressure on luminous intensity.

\section{Conclusion}

PVC was found to be the binder of choice for red flares; as it has a dual function as a binder and color intensifier (source of chlorine). The released chlorine upon PVC combustion exhibited an effective rule to support the formation of $\mathrm{SrCl}$ (the main red color main emitting species). Al fuel was found to eliminate the formation of incandescent emitters ( $\mathrm{MgO}$ and $\mathrm{SrO}$ ). Furthermore $\mathrm{Al}$ supported the formation of $\mathrm{SrCl}$ which is main red color emitting species; consequently high quality color can be developed.

The optimization between the color intensifier $(\mathrm{PVC})$ and the color source $\left(\mathrm{Sr}\left(\mathrm{NO}_{3}\right)_{2}\right)$ with $\mathrm{Al}$ fuel was found to have the greatest impact for enhance luminous intensity and color quality. These parameters were optimized to develop red flare with enhanced spectral performance $\left(F_{12}\right)$. It exhibited an increases the luminous intensity by $72 \%$; also the red band spectrum $(650-750 \mathrm{~nm})$ was enhanced by $60 \%$ to the standard reference flare. This enhanced performance was achieved by using $\mathrm{Al}$ fuel and implementing the general rule by implementing the general rule that the color intensifier should be in the range from 10-15 Wt.\% of the total composition. The optimum pressing pressure for sample preparation was found to be 50 bars. Higher pressure could be detrimental for spectral performance.

\section{References}

[1] Brock, A.S.H., Pyrotechnics: The History and Art of Firework Making. 1922: Daniel O'Connor.

[2] Russell, M.S. and R.S.o. Chemistry, The Chemistry of Fireworks. 2000: Royal Society of Chemistry.

[3] ELLERN, D.H., Military and Civilian Pyrotechnics. 1968, United States of America: CHEMICAL PUBLISHING COMPANY INC.

[4] Conkling, J.A. and C. Mocella, Introduction, in Chemistry of Pyrotechnics: Basic Principles and Theory, Second Edition. 2010, CRC Press. p. 1-6.

[5] Shimizu, T., Fireworks: The Art, Science, and Technique. 1996: Pyrotechnica Publications.

[6] Bebie, J., Manual Of Explosives Military Pyrotechnics And Chemical Warfare Agents.

[7] Kosanke, K.L., et al., Encyclopedic Dictionary of Pyrotechnics: (and Related Subjects). 2012: Journal of Pyrotechnics, Incorporated.

[8] Conkling, J.A. and C. Mocella, Chemistry of Pyrotechnics: Basic Principles and Theory, Second Edition. 2010: CRC Press.

[9] Shidlovsky, A., Principles of pyrotechnics. 3rd edition ed. 1974. 
Military Technical College

Kobry El-Kobbah,

Cairo, Egypt

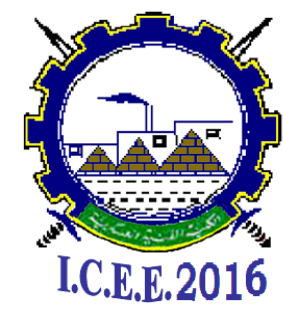

$8^{\text {th }}$ International Conference

on

Chemical \& Environmental

Engineering

$19-21$ April 2016

[10] Command, U.S.A.M., Engineering design handbook: Theory and application, U.S.A.M. Command, Editor. 1967, Military Pyrotechnic Series: Washington, DC. p. (AMC Pamphlet 706-185).

[11] Ledgard, J., The Preparatory Manual of Black Powder and Pyrotechnics. 2006: Lulu Enterprises Incorporated.

[12] Johnston, S.F., A History of Light and Colour Measurement: Science in the Shadows. 2001: CRC Press.

[13] Shidlovskiy, A.A., Principles of pyrotechnics. Vol. Third edition. 1964, Moscow.

[14] Hardt, A.P., et al., Generation of Light, in Pyrotechnics. 2001, Pyrotechnica Publications. p. 277 - 298.

[15] Conkling, J.A. and C. Mocella, Basic chemical principles, in Chemistry of Pyrotechnics: Basic Principles and Theory. 2010, CRC Press. p. 7- 57.

[16] Ellern, H., Modern Pyrotechnics. Fundamentals of Applied Physical, 1961.

[17] Dillehay, D.R., Illuminants and illuminant research. Journal of Pyrotechnics, 2004: p. 53-60.

[18] Ellern, H., Underlying Phenomena, in Military and Civilian Pyrotechnics. 1968, CHEMICAL Publishing Company Incorporated (NY). p. 87 - 98.

[19] Douda, B. and N.A.D.C. IN, Theory of Colored Flame Production. 1964: Defense Technical Information Center.

[20] Kosanke, K.L.K.a.B.J., The chemistry of colored flames. Journal of Pyrotechnics, 2004.

[21] Conkling, J.A. and C. Mocella, Color and light production, in Chemistry of Pyrotechnics: Basic Principles and Theory. 2010, CRC Press. p. 179 - 202.

[22] Ellern, H., Colored Lights, in Military and Civilian Pyrotechnics. 1968, CHEMICAL Publishing Company Incorporated (NY). p. 122 - 130.

[23] Hardt, A.P., et al., Color creation, in Pyrotechnics. 2001, Pyrotechnica Publications. p. $39-43$.

[24] Weingart, G.W., Pyrotechnics. 2001: Survival Press.

[25] Tro, N., Chemistry in Focus: A Molecular View of Our World. 2015: Cengage Learning.

[26] Kosanke, K.L. and B.J. Kosanke, Selected Pyrotechnic Publications of KL and BJ Kosanke, Part 1: 1981 Through 1989. 1995: Journal of Pyrotechnics.

[27] Meyerriecks, W. and K. Kosanke, Color values and spectra of the principal emitters in colored flames. J. Pyrotechnics, 2003. 18: p. 1-22.

[28] Bailey, A. and S.G. Murray, Pyrotechnics, in Explosives, Propellants and Pyrotechnics. 2000, Brassey's. p. 115-140.

[29] Army, U.S.D.o.t., Military Explosives. 1989: Headquarters, Department of the Army.

[30] Tuukkanen, I.M., et al., Pyrotechnic and Thermal Studies on the Magnesium-Strontium Nitrate Pyrotechnic System. Propellants, Explosives, Pyrotechnics, 2006. 31(2): p. 110115.

[31] Conkling, J.A. and C. Mocella, Components of High-Energy Mixtures, in Chemistry of Pyrotechnics: Basic Principles and Theory. 2010, CRC Press. p. 59 - 96. 
Military Technical College

Kobry El-Kobbah,

Cairo, Egypt

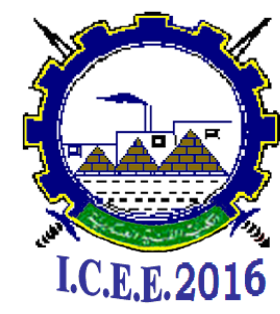

$8^{\text {th }}$ International Conference

on

Chemical \& Environmental

Engineering

$19-21$ April 2016

[32] Wada, Y., N. Foster, and T. Yoshida, Safety of Reactive Chemicals and Pyrotechnics. 1995: Elsevier Science.

[33] DEFENSE, U.S.O., DOD Contractor's Safety Manual For Ammunition and Explosives. 2008.

[34] Ellern, H., Magnesium and Aluminum, in Military and Civilian Pyrotechnics. 1968, CHEMICAL Publishing Company Incorporated (NY). p. 328 - 331.

[35] Lee, J.D., CONCISE INORGANIC CHEMISTRY, 5TH ED. 2008: Wiley India Pvt. Limited.

[36] Shimizu, T., Part 4. Pyrotechnics, in Fireworks: The Art, Science, and Technique. 1996, Pyrotechnica Publications. p. 85 - 177.

[37] Jackson Jr, B., et al., Substitution of Aluminum for Magnesium as a Fuel in Flares. 1975, DTIC Document.

[38] Lăzăroaie, C., et al., Temperature measurements of magnesium-and aluminum-based flares. Journal of Thermal Analysis and Calorimetry, 2014. 115(2): p. 1407-1415.

[39] Ernst-Christian Koch, J.J.S., Jay C. Poret, Jared D. Moretti, New Pyrotechnic Signal Flare Compositions Based on Cheap Established and Environmentally Acceptable Ingredients, in Energetic Materials: Performance, Safety and System Applications. 2015, Fraunhofer ICT: Germany. p. 1-8.

[40] Siekierski, S.C. and J. Burgess, Concise Chemistry of the Elements. 2002: Elsevier Science.

[41] Kosanke, K., et al., Pyrotechnic Chemistry, Pyrotechnic Reference Series, No. 4. Journal of Pyrotechnics, Inc, 2004.

[42] Ellern, H., Formulas, in Military and Civilian Pyrotechnics. 1968, CHEMICAL Publishing Company Incorporated (NY). p. 353 - 387.

[43] Rapidtables. Online Scientific and Engineering Resource. Lux to candela calculator 2014; Available from: http://www.rapidtables.com/calc/light/lux-to-candelacalculator.htm.

[44] DOUDA, B., Spectral observations in illuminating flames(Spectrum analyses on illuminating flames caused by magnesium-sodium nitrate combustion). 1968.

[45] Conkling, J.A. and C. Mocella, Pyrotechnic principles, in Chemistry of Pyrotechnics: Basic Principles and Theory. 2010, CRC Press. p. 97 - 113.

[46] Agrawal, J.P., High Energy Materials: Propellants, Explosives and Pyrotechnics. 2010: Wiley.

[47] Wikipedia, S. Explosive material. 2015; Available from: https://en.wikipedia.org/wiki/Explosive_material. 
Military Technical College Kobry El-Kobbah,

Cairo, Egypt

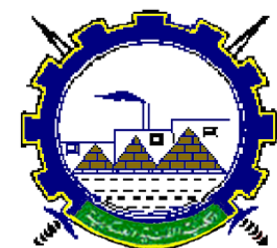

I.C.E.E.2016 $8^{\text {th }}$ International Conference

on

Chemical \& Environmental

Engineering

19-21 April 2016

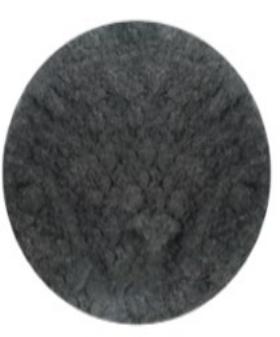

Ingredient mixing with binder

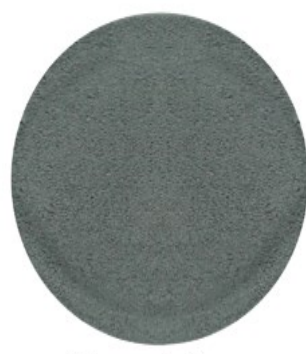

Granulation

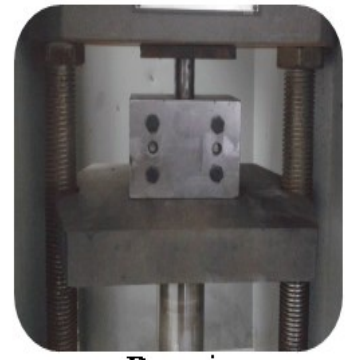

Pressing

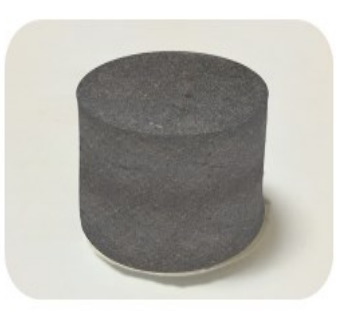

Final flare grain

Fig. 1: The main manufacture steps of red flares

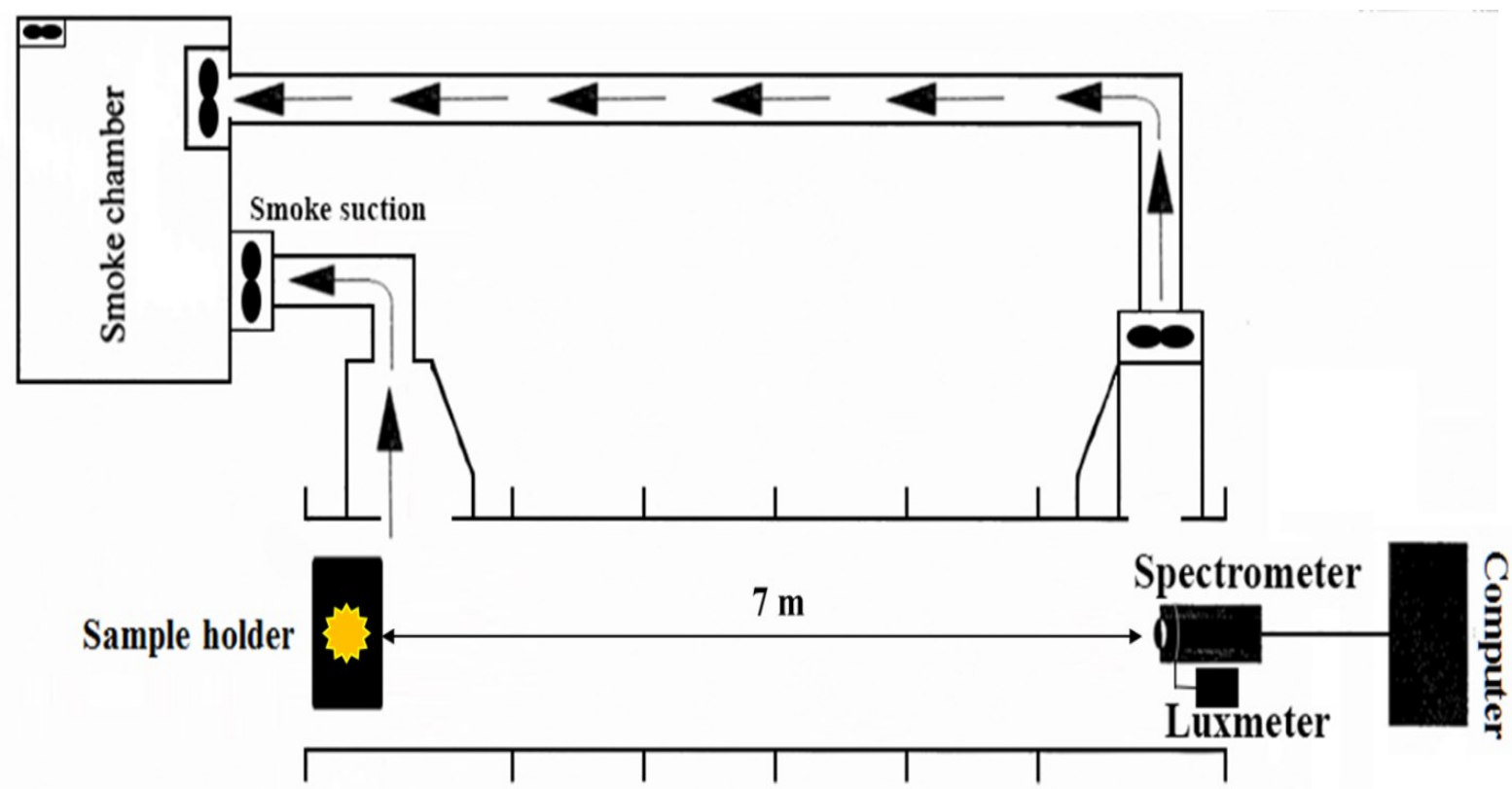

Smoke tunnel

Fig. 2: Schematic for spectra measurements of developed red flares 
Military Technical College Kobry El-Kobbah,

Cairo, Egypt

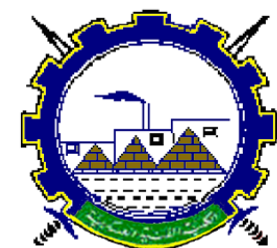

I.C.E.E.2016 $8^{\text {th }}$ International Conference on

Chemical \& Environmental Engineering

$19-21$ April 2016

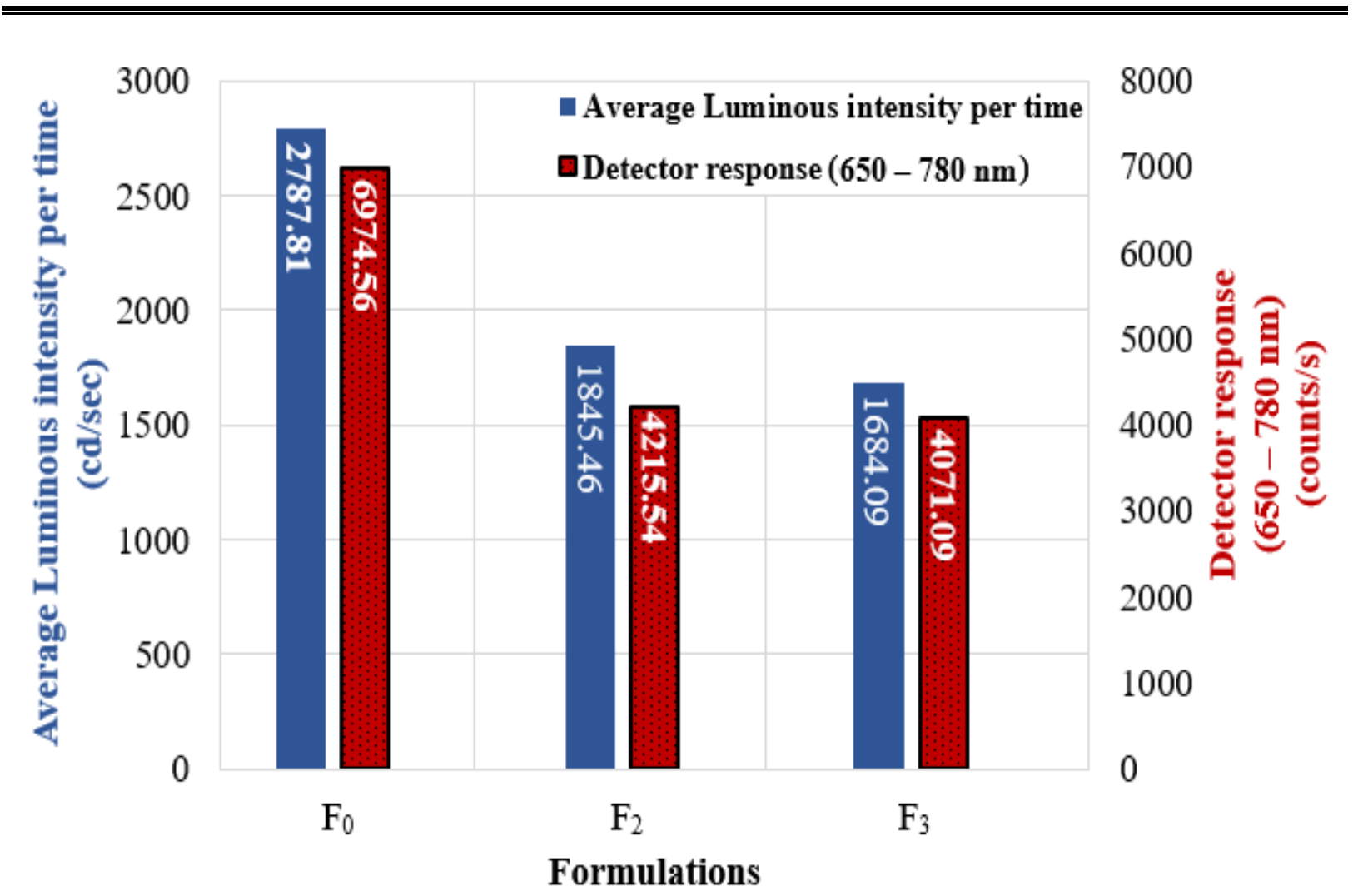

Fig. 3: Effect of binder type on the luminous intensity in (cd/s)

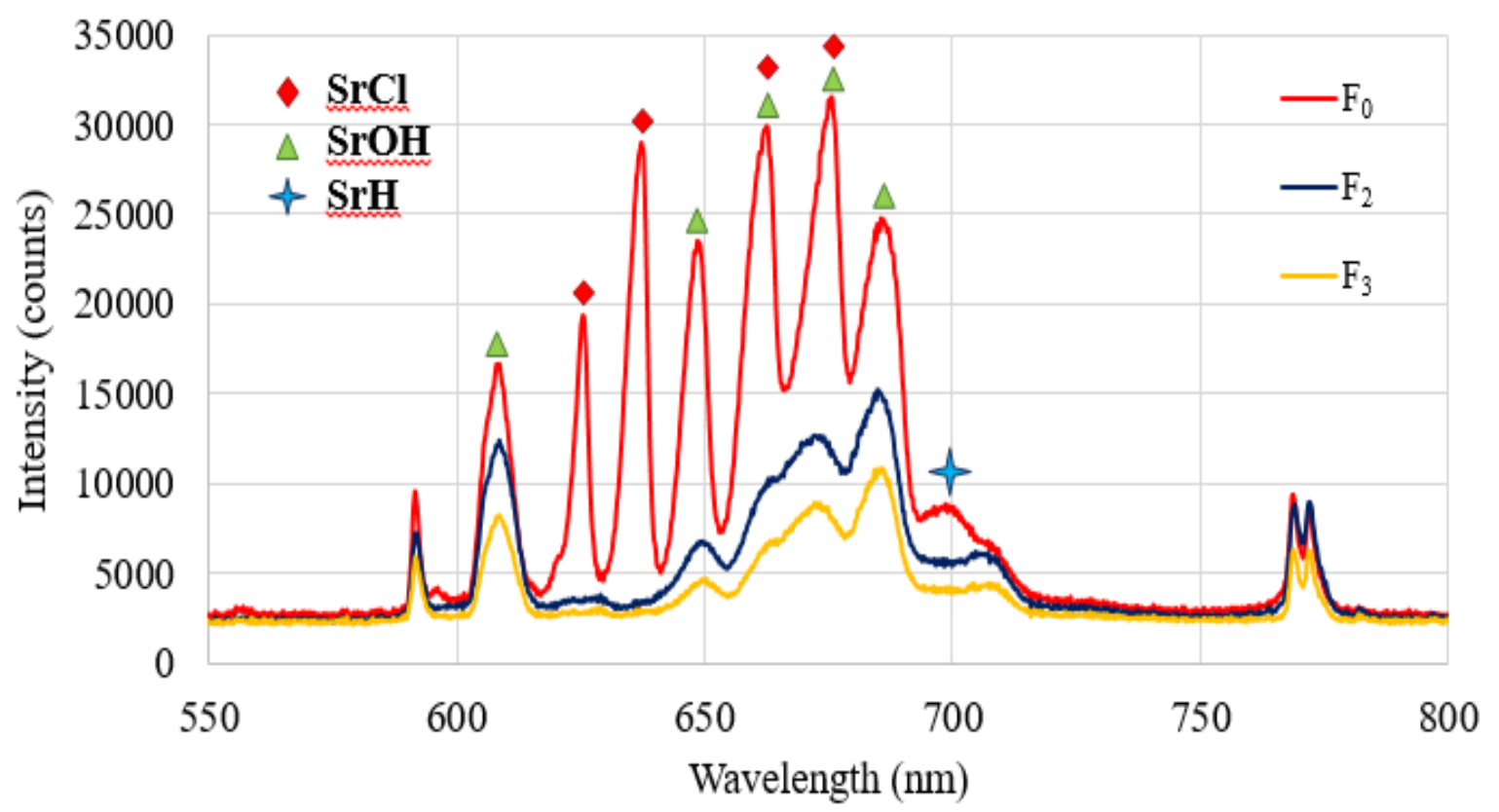

Fig. 4: The impact of binder type on the imprint spectrum red flares. 
Military Technical College

Kobry El-Kobbah,

Cairo, Egypt

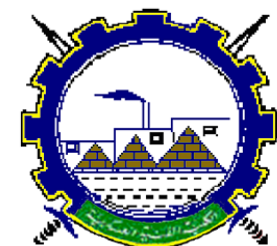

I.C.E.E.2016 $8^{\text {th }}$ International Conference

on

Chemical \& Environmental

Engineering

19-21 April 2016

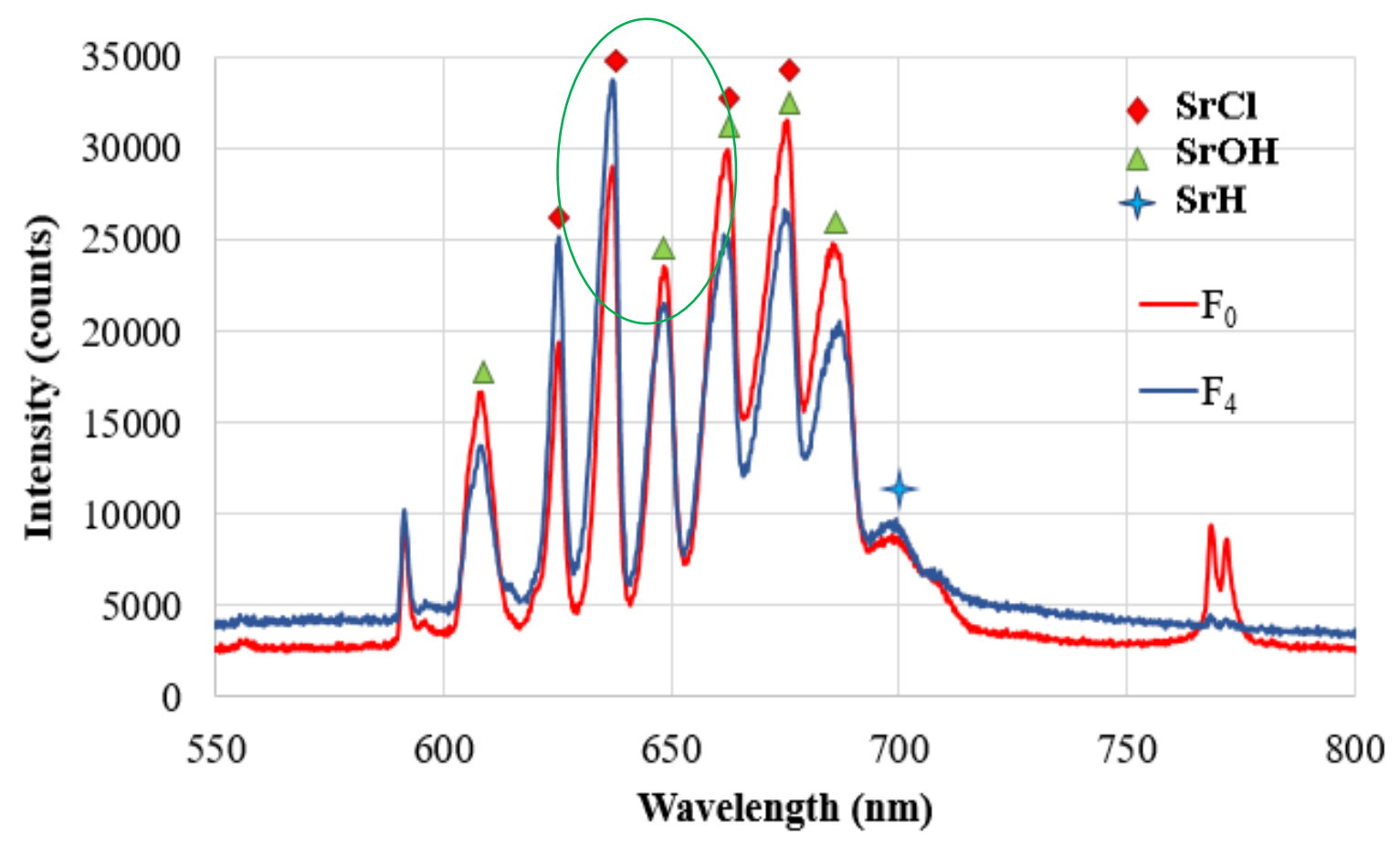

Fig. 5: The impact of fuel type on the imprint spectrum red flares
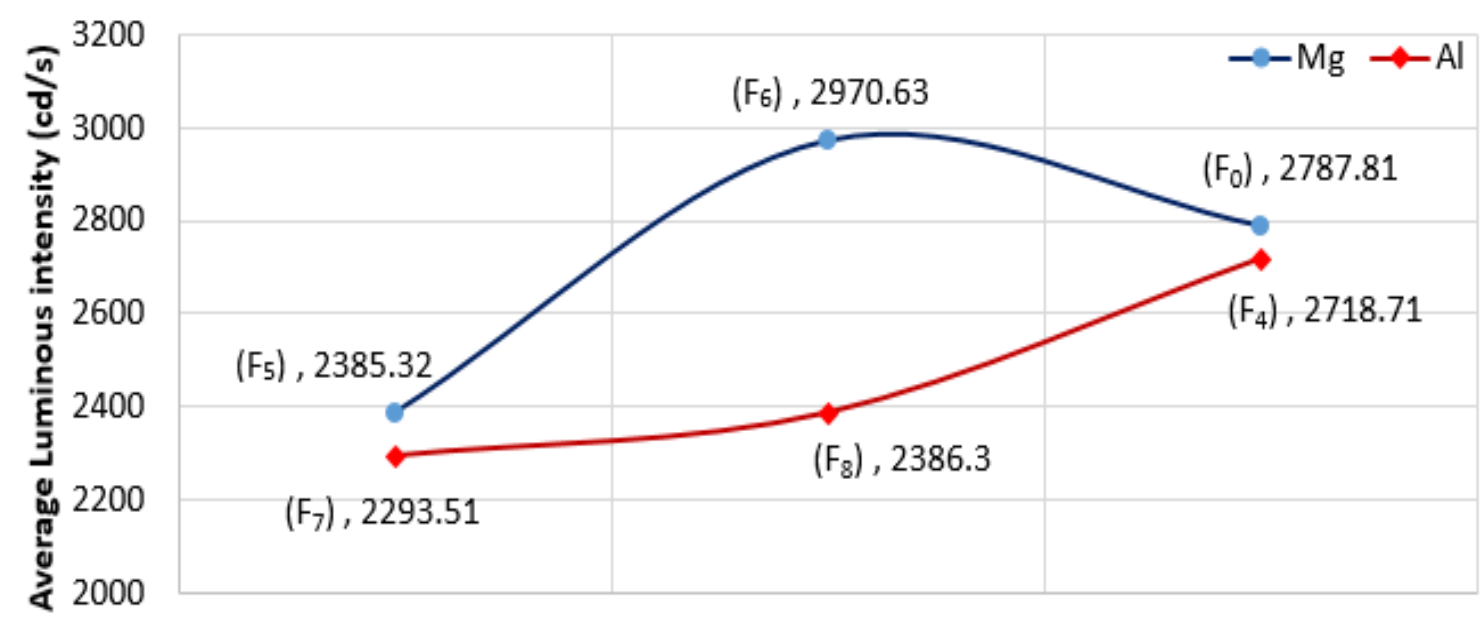

22

25

28

Fuel Wt.\%

Fig. 6: Effect of fuel type/content on the luminous intensity in (cd/s) 
Military Technical College Kobry El-Kobbah,

Cairo, Egypt

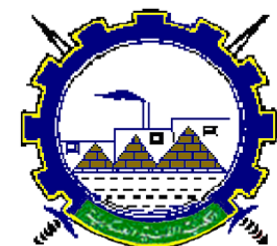

I.C.E.E.2016 $8^{\text {th }}$ International Conference

on

Chemical \& Environmental

Engineering

19-21 April 2016

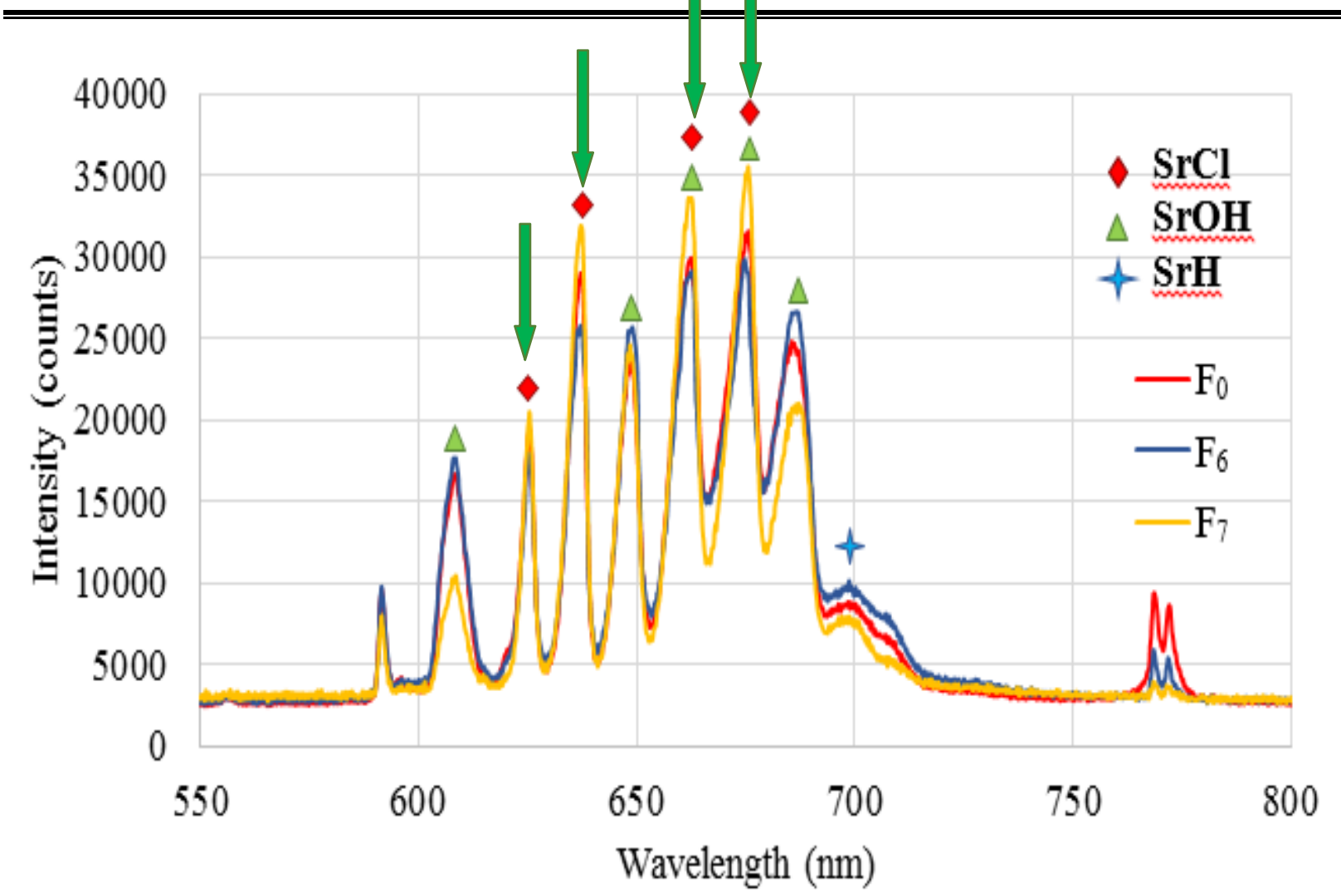

Fig. 7: Imprint spectrum of formulations $F_{0}, F_{6}$ and $F_{7}$

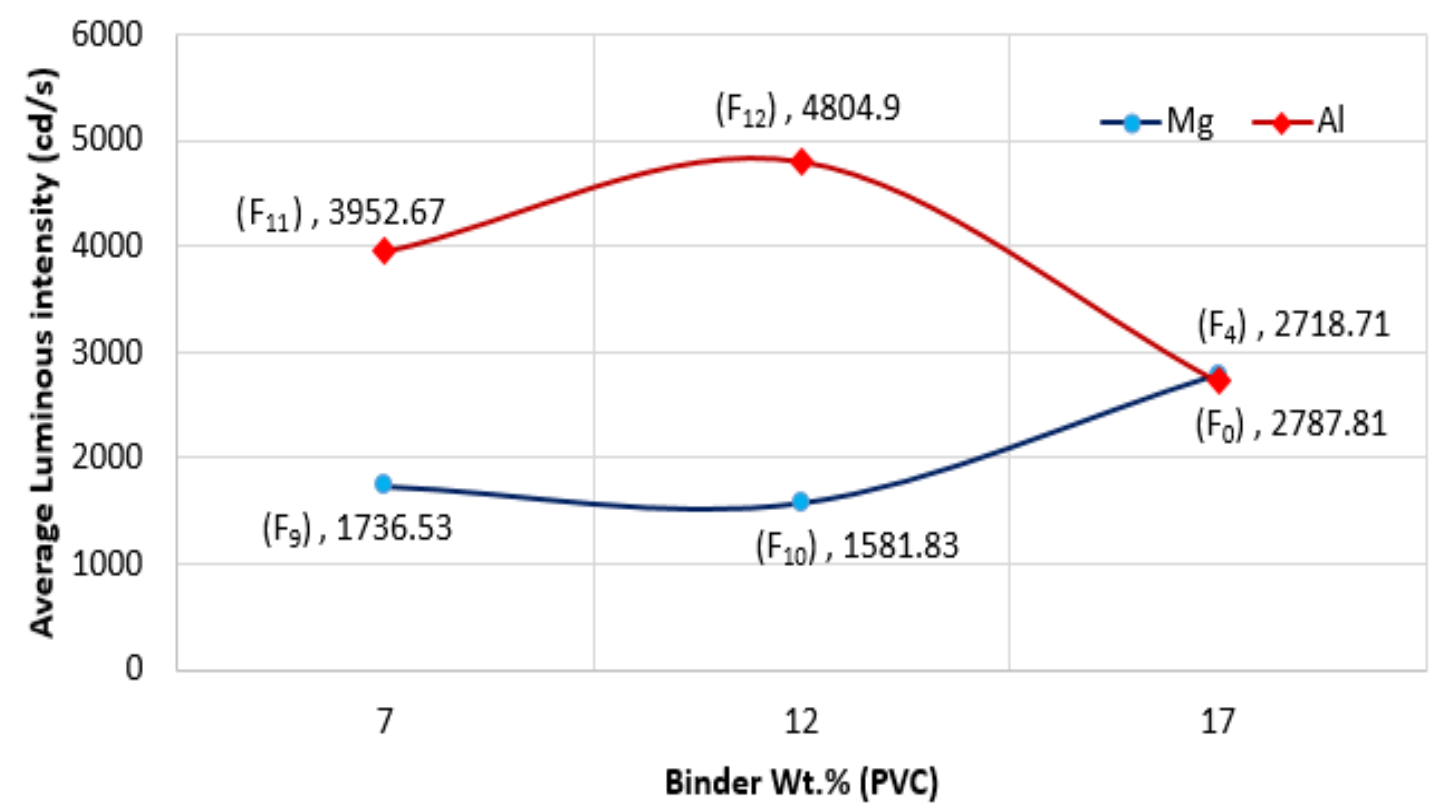

Fig. 8: Effect of color source to color intensifier on the luminous intensity in (cd/s) 
Military Technical College Kobry El-Kobbah,

Cairo, Egypt

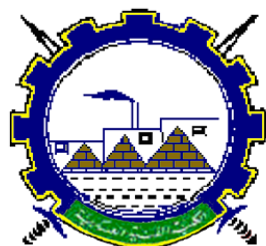

I.C.E.E.2016 $8^{\text {th }}$ International Conference

on

Chemical \& Environmental

Engineering

$19-21$ April 2016

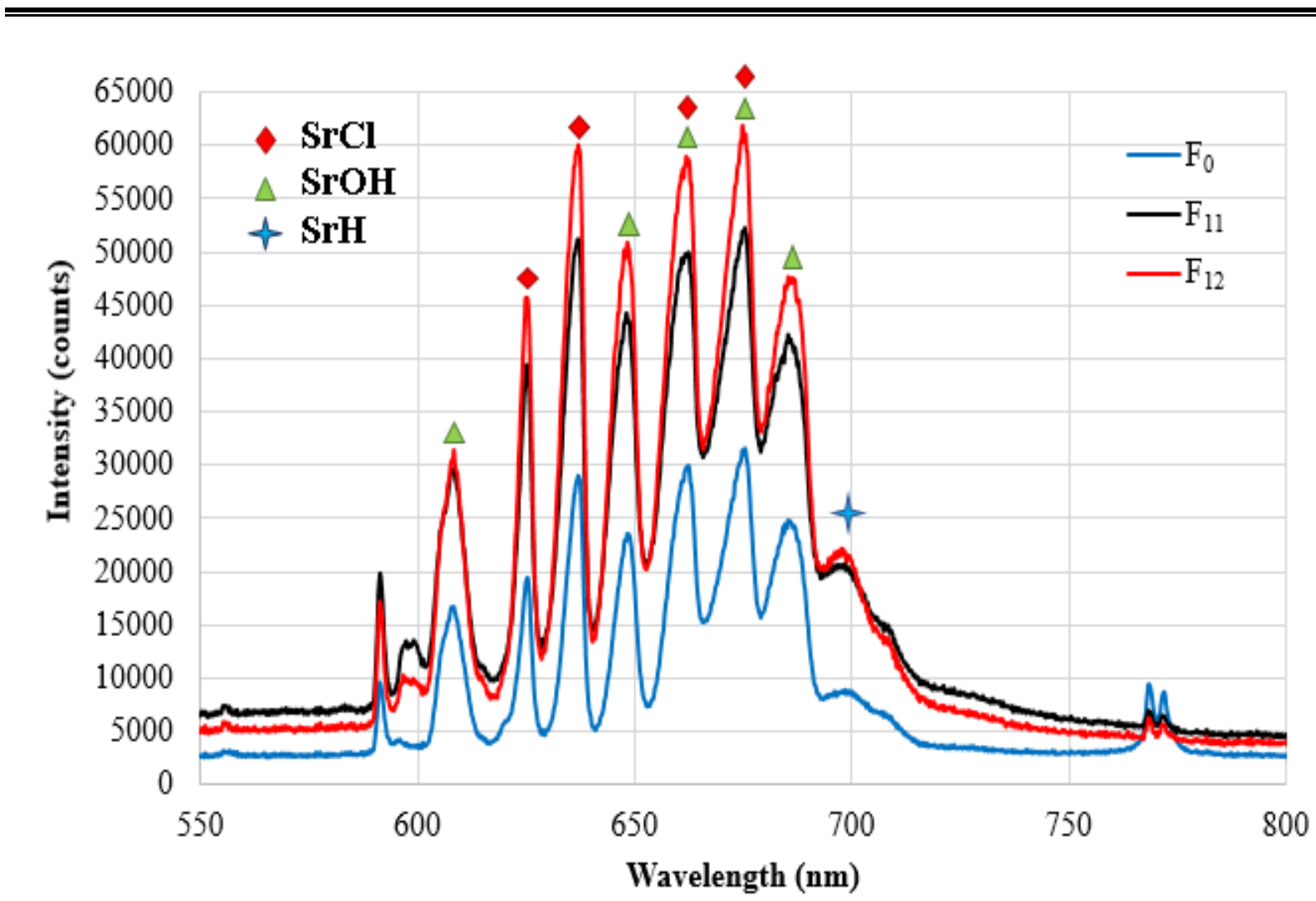

Fig. 9: Imprint spectra of developed red flared $\left(F_{11}\right.$ and $\left.F_{12}\right)$ to reference red flare $\left(F_{0}\right)$
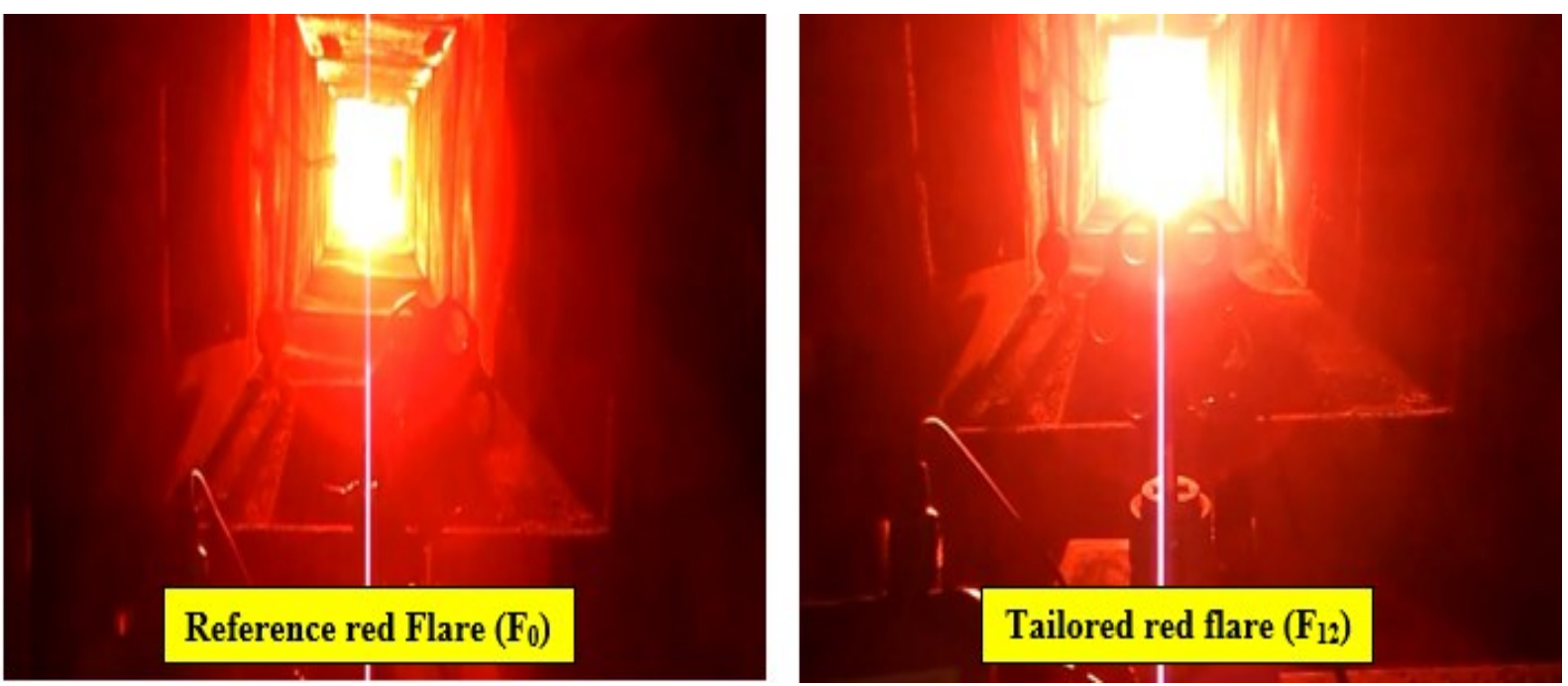

Fig. 10: Representative digital photographs of developed red flare $\left(F_{12}\right)$ to reference flare 
Military Technical College Kobry El-Kobbah,

Cairo, Egypt

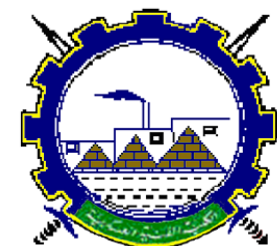

I.C.E.E.2016 $8^{\text {th }}$ International Conference

on

Chemical \& Environmental

Engineering

$19-21$ April 2016

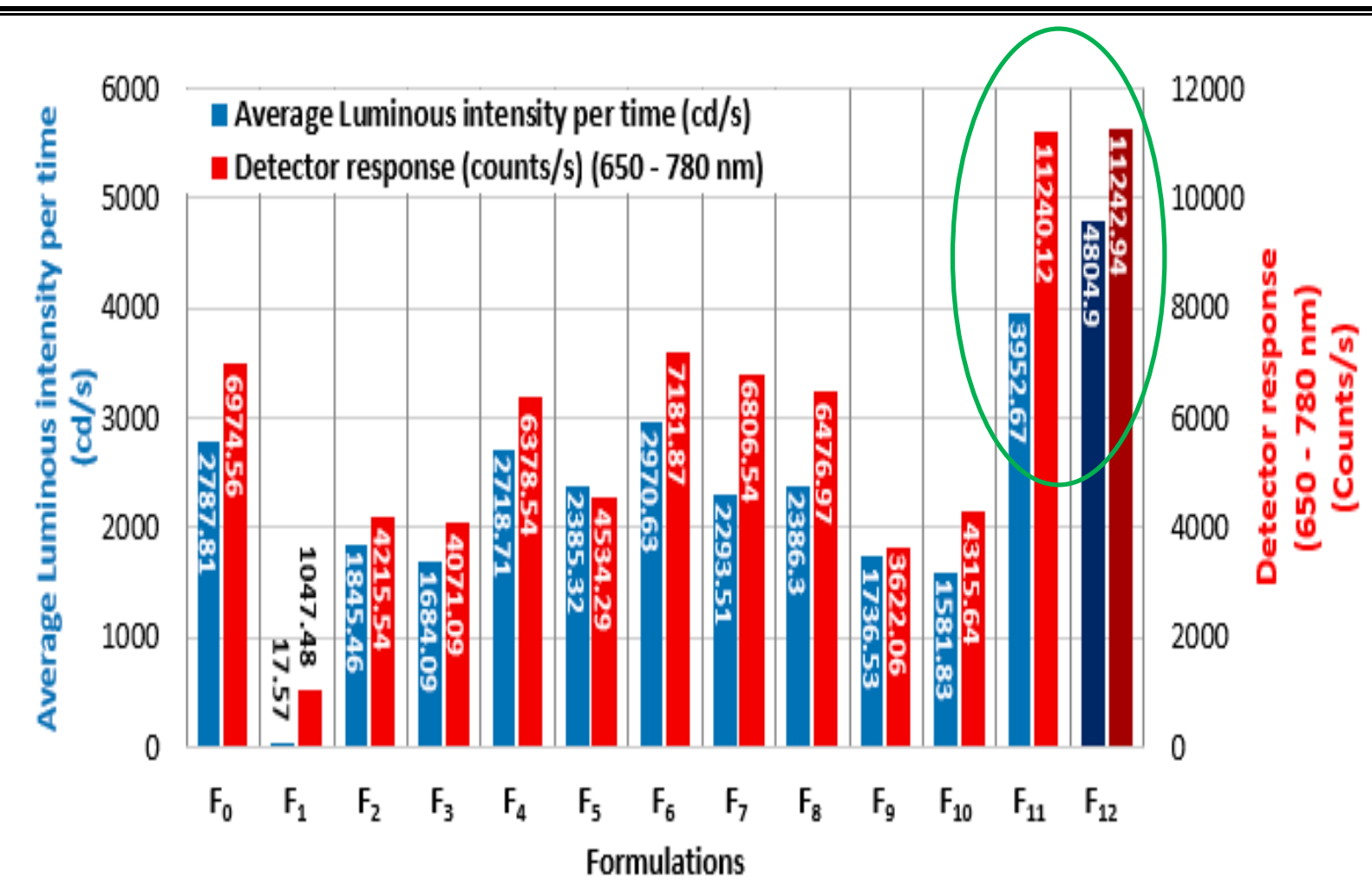

Fig. 11: Variation of average luminous intensity per time and detector response with different formulations

Loading pressure effect

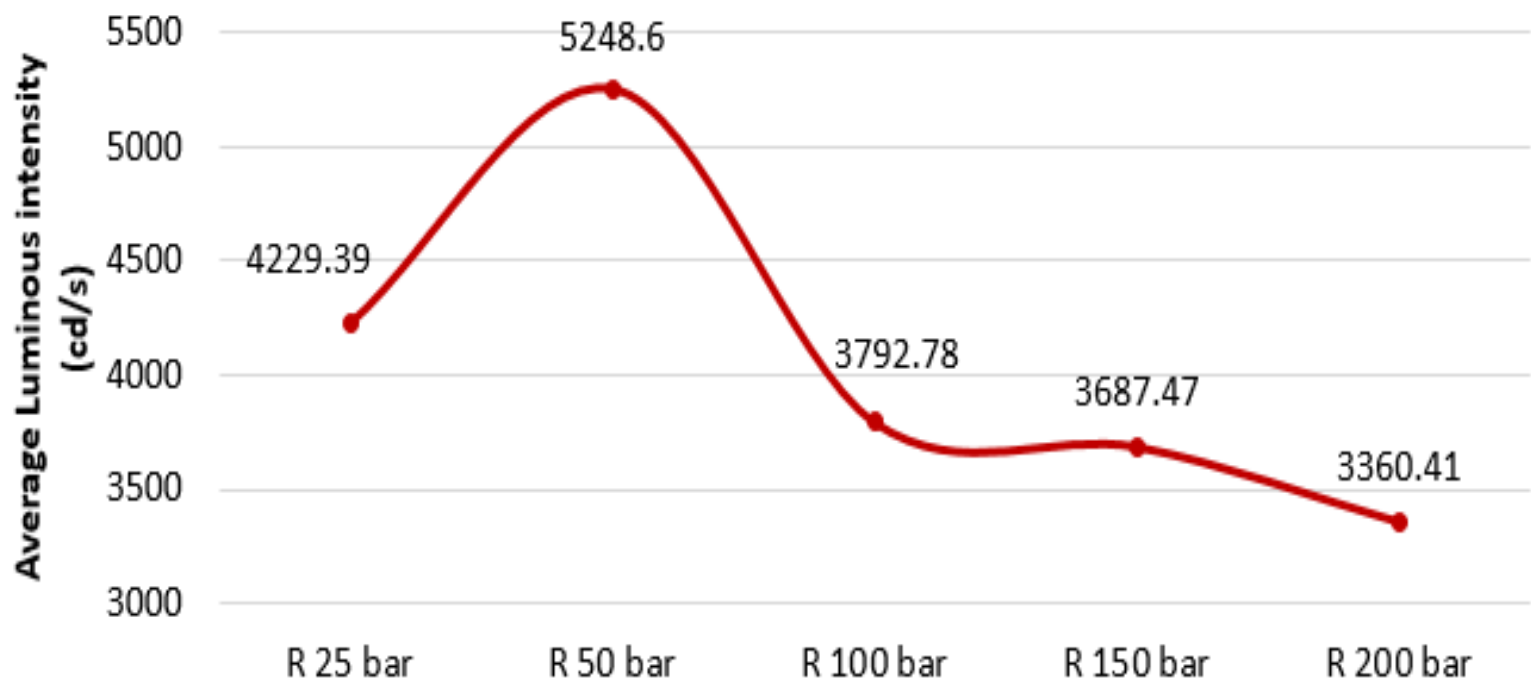

Fig. 12: loading pressure effect on the average luminous intensity per time of the tailored red flare $\mathbf{F}_{12}$ 